\title{
Hermeneutic Praxis: The Yoga of Reason(ing)
}

\author{
Karl-Stéphan Bouthillette \\ Institut für Indologie und Tibetologie \\ Ludwig-Maximilians-Universität München
}

\begin{abstract}
Could the presuppositions behind the distinction between theory and practice in the realm of yoga be misguided, if not misleading? To approach this question, this paper drafts a meta-perspective gleaned from the thought of three thinkers credited with the earliest Indian doxographies, namely the sixth-century philosopher of Madhyamaka Buddhism, Bhāviveka, the seventh-century Jaina logician Haribhadra Sūri, and the eighth-century Advaita-Vedānta philosopher Śankkarācārya. The paper examines the notion of "view" entertained in Indian thought, and suggests that yoga is particularly interested in shaping views. It draws a distinction between the notions of "practice" and "praxis," arguing that the latter best captures the "yoga" of our authors. The paper then discusses the transformative role of hermeneutics and how, when combined with dialectic, it captures the essence of "scholastic praxis." Finally, it presents a traditional framework to elucidate the interplay of hermeneutic praxis and soteriology within Buddhism, with brief references to similar patterns in the work of our two non-Buddhist authors. The self-transformative aspect of hermeneutics has so far received little attention and requires further research. This paper is an attempt in that direction.
\end{abstract}

Key words: yoga, reasoning, dialectic, hermeneutics, praxis

Słowa kluczowe: yoga, rozumowanie, dialektyka, hermeneutyka, praxis

There is a common problematic entertained within various modern religious discourses, including the ideological nebula known as yoga, to the effect that there exists a clear distinction between theory and practice. The embodied correlatives of such a division are those commonly designated as "scholars" and "practitioners." Could the presuppositions behind this distinction, especially in the realm of yoga, be misguided, if not misleading? To approach this question, this paper will draft a meta-perspective gleaned from the ideas of three thinkers credited with the earliest Indian doxographies, namely the sixth-century philosopher of Madhyamaka Buddhism Bhāviveka; the seventh-century Jaina logician Haribhadra Sūri; and the 
eighth-century Advaita-Vedānta philosopher Śañkarācārya. ${ }^{1}$ Owing to space limitations, however, Bhāviveka will be given special attention.

Beyond doxography, Bhāviveka, Haribhadra and Śankara had something else in common: they were all dedicated to the study, exposition and defence of what they perceived as the best way to achieve the end goal of religious life, liberation. Although their views clashed on major doctrinal points, they agreed on some basic notions, notably regarding the liberating event of the actualisation of a state of consciousness where the absence of suffering ( $d u h k h a)$ is commensurable with the presence of supra-mundane knowledge (jñana) and the cessation of cyclic existence (samsāra). These three staunch debaters would have had no qualms in presenting their path as a form of yoga, if not as the best of its kinds. Now, if they had been asked whether they consider themselves to be scholars or practitioners of yoga, how would they have responded?

One could outline their opinions in different ways. Out of caution about the amount of space available, this paper will attempt a short-cut. It will jump directly to the notion of "views" entertained in Indian thought, using it as a guiding thread throughout the discussion, suggesting that yoga is particularly interested in shaping views. A distinction between the notions of "practice" and "praxis" will be drawn, arguing that the latter best captures the "yoga" of these authors. The discussion will then move on to the transformative role of hermeneutics and how, when combined with dialectic, it captures the essence of "scholastic praxis." Finally, the paper will present a traditional framework to elucidate the interplay of hermeneutic praxis and soteriology within Buddhism, with brief references to similar patterns in the work of the two non-Buddhist authors. The self-transformative aspect of hermeneutics has so far received little attention and requires further research. This paper is an attempt in that direction.

\section{Views and philosophy}

Wilhelm Halbfass discussed how, among the common doxographical terms generally used in Sanskrit to denote philosophical tenets, like nitti or naya, the word darśana gradually became standard. ${ }^{2}$ Meaning "vision," it is formed from the verbal root $d r{ }^{\prime}$, to see. Thus, in the context of philosophy, a darśana comes to mean a certain way of seeing the world, or a worldview. Here is a direct connection with our initial question. Drawing from the Greek meaning of theoria, a theory can also be said to present a certain "vision," a "contemplation" of some sort. In that sense, when our doxographers engage with darśanas, they are mainly concerned with theories. But would that be enough to assume that they are less concerned with "practice"?

${ }^{1}$ The authorship of the Sarva-darśana-siddhānta-samgraha, better known as Sarva-siddhāntasamgraha, traditionally attributed to Śan்karācārya, is debatable.

${ }^{2}$ See Darśana, Ānvīkșikī, Philosophy [in:] W. Halbfass, India and Europe: An Essay in Understanding, New York 1988, pp. 263-286. Also: idem, Observations on Darśana, "Wiener Zeitschrift für die Kunde Südasiens" 1979, vol. 23, pp. 195-203. 


\section{Practice and praxis}

At this point, let us consider the meaning of "practice." The word itself can be traced back to the Greek praxis $(\pi \rho \tilde{\alpha} \xi 1 \varsigma)$, or to praktike ( $\pi \rho \alpha \kappa \tau \iota \kappa \eta ́)$. While praktike refers to someone or something fit for action, from the verbal root prasso $(\pi \rho \alpha ́ \sigma \sigma \omega)$, "to accomplish or to bring about," the word praxis had a more prosperous development in philosophy, initiated by Plato. Within the concept of praxis are woven the notions of action and ideation. Praxis refers to an effort to engage with or to realise an idea. In a religious context, praxis can take on the meaning of the immediate experience of what had so far been known only through concepts. Union with God, for example, would be a mystical feat accomplished through praxis, where, to cite Saussure's terminology, the signifier word for God and its signified meaning would be transcended by a first-hand experience of the very object lying behind the linguistic sign. This leads us to suggest that, in the context of the yoga nebula, the notions of "practice" and "practitioners" are to be understood within the religious semantic of prax$i s$. A practitioner of yoga would thus be someone engaged in the process of experiencing the theories supporting a certain yogic worldview. This is suggested by the author of Yoga Tantra: Theory and Praxis, Tomy Augustine: "The term 'praxis' sums up the entire realm of tantric practices adopted by the Vajrayānists. [...] 'Praxis' is closer to principles than to practices; it is applied principles and distinct and differentiated from static theories." ${ }^{3}$ Could this last distinction observed by Augustine be the dividing line between "scholars" and "practitioners"? On the one hand, there would be people involved in actuating the yogic worldview - they would be "practitioners" - while on the other would be people strictly dealing with static theories - "scholars."

Now, one might wonder if these categories are two equal sides of the same coin, or if one is better than the other. If we were to look at this division from the standpoint of Hannah Arendt, who revived the notion of praxis in political thought, the connotations given to the socio-political dimensions of these two categories would become obvious. The "practitioner," engaged in praxis, would take on the colourful flag of participatory democracy and political activism, while the greyish "scholar," stuck in static theories, would stand for the boring bureaucrats and conservative elite. Clearly, a worldview entertaining such a clear-cut schism is unlikely to give much value to the scholastic. Yet it is equally unlikely to attach any value to the meaning of its practice besides sentimental connotations of the order of likes and dislikes. Upon closer examination, our initial question begins to sound like a Zen kōan: "What is the worth of a meaningless practice?"

If praxis consists in producing, evaluating and applying theories, the contemplation of ideas can be said to be its motor, its very essence. In other words, there would be no praxis without a supporting theoretical framework; what we can call a "worldview," which involves a set of principles constituting the metaphysical armature of the given system of reference. Moreover, in the context of yoga as understood by our

${ }^{3}$ T. Augustine, Yoga Tantra: Theory and Praxis, in the Light of the Hevajra Tantra, a Metaphysical Perspective, Bibliotheca Indo-Buddhica Series, Delhi 2008, p. 5. 
three authors, the outcome of praxis is said to lead to a total transformation of the mundane theoretical framework associated with samsāra. As we shall see, while the final outcome of that path might be said to lie beyond views altogether, the buildup to that experience and its subsequent communication involve a careful assimilation of what can be called a "palliative" non-mundane view. This assimilative process, constitutive of the overall yogic therapy, requires a disciplined hermeneutical method where engaging with views - especially one's own - is fundamental. In this context, hermeneutics, or exegesis, a discipline too often associated with dry scholastic, or "static theories," is part and parcel of the soteriological transformative process called the "path" (märga).

\section{Hermeneutics as a self-transformative process}

The kind of hermeneutics in which doxographers engaged is a later departure from an older tradition of critical examination of authoritative scriptures. This former practice was observed, for example, even in the early Indian Buddhist context, where it was designated by the term "parīkșa" (critical examination), which Vincent Eltschinger, while discussing the apologetical dimensions of Buddhist epistemology, provisionally defined as: "the evaluation, by means of reason(ing) (identified or not to the pramannas) and/or scripture (provided the opponent belongs to the same confessional denomination), of an opponent's theoretical and/or practical tenets in order to assess their rationality and, further, the soteriological relevance of the system as a whole [...]." Eltschinger argues that this dialectical practice heralded the later hetuvidy $\bar{a}$ (science of reasoning), which not only served apologetical purposes, but was also considered to support religious praxis as a precondition to the reflective and meditative parts of the path, ${ }^{5}$ by removing false views and their corresponding ill-conceived actions. In other words, the hermeneutical tools of critical examination, such as the pramannas, became self-transformative tools in their own right, shaping one's worldview while assessing those of others.

In modern times, Mircea Eliade was the first scholar of religions to point out the transformative impact of hermeneutics on its practitioner. In one controversial passage he stated that: "En fin de compte, l'herméneutique créatrice change l'homme, elle est plus qu'instruction, elle est aussi une technique spirituelle susceptible de modifier la qualité même de l'existence." ${ }^{\prime 6}$ Nowadays, one risks little in moving beyond Eliade to observe that exegesis not only affects the individual, but also shape societies and cultures. In India, it is the leitmotiv of the śāstric tradition. This essential exegetical dimension of Indian religious traditions tends to be overshadowed by the glamour of mystical feats. In fact, one could read the various darśanas as different

${ }^{4}$ V. Eltschinger, Buddhist Epistemology as Apologetics, Studies on the History, Self-Understanding and Dogmatic Foundations of Late Indian Buddhist Philosophy, Beiträge Zur Kultur- und Geistesgeschichte Asiens, vol. 81, Wien 2014, pp. 18-19.

${ }^{5}$ Ibidem, p. 192.

${ }^{6}$ M. Eliade, La Nostalgie des Origines. Méthodologie et Histoire des Religions, Paris 1971, p. 108. 
exegetical theories developed progressively through what the classicist André Laks calls a "communauté communicationelle,"7 a communicating community born out of a movement of "auto-référentialisation." The progressive development of the doctrine of the two truths, which took centre stage in Madhyamaka Buddhism, is but one example of this phenomenon, well captured by John B. Buescher. There is both a historical and a philosophical danger in reifying the various darśanas as some kinds of establishment with "pignon sur rue."

Coming back to Eliade's statement about the transformative effect of hermeneutics, authors of Indian śästras, like our doxographers, would have agreed that the rigorous study of texts, the effort to extract their meaning, is a transformative process, an effective spiritual praxis in itself. At the very least, they would have granted that the kind of self-study (svādhyāya) involved in exegesis is the efficient cause of removing doubt and false views, both major obstacles on the path. When Jaimi, founder of Mīmāmsā exegesis, calls for the conduct of an in-depth inquiry into dharma, at the very beginning of his opus magnum, the Mìmāmsā Sütras, he chooses his words carefully: "athāto dharmajijñāsā" (therefore, there must be a desire to know dharma). "Jijñass $\bar{a}$ " "the desire to know," is the very heart of exegesis. This discipline does not simply care for the elucidation or memorisation of some static theories, to paraphrase Augustine. It requires a genuine motivation to engage in the "praxis of knowing," knowing dharma through Vedic exegesis. Although strictly intellectual at first sight, this praxis is designed to affect one's behaviour by directing it through the injunctions of dharma. But how does one know dharma, or anything at all for that matter?

In order to bring about the desired result, ascertainment (nirnaya) of the object of analysis, the removal of doubt, since textual authority (śabda-pramāna) such as the validity of the Vedas is disputed among men, or because scriptures may appear defective in some ways, exegetes cannot rely on textual proof alone. For thinkers like Bhāviveka, Haribhadra and Śankkara, the crucial exercises of self-analysis and of reflection on the nature of reality must survive the test of reason(ing) (yukti). There lies the real kuruksetra of exegesis. For example, in his discussion on Mīmāṃsā, in the Madhyamakahrdaya (MHK), Bhāviveka stresses the need to ascertain what is true (tattva), or factual, instead of relying on the authority of some scripture: "Concerning the scriptural authority of scriptures based upon an uninterrupted transmission. Since, of all [scriptures], the authority is not established, what should be agreed upon is what is truth" (MHK: 9.19). ${ }^{8}$ And what is true (kim tattvam) can only be agreed upon through impartial reasoning, as Bhāviveka pointed out in verse 18: "From here onward, those seeking facts as they are will examine that [demonstration (nirnaya)], after having abandoned the poison of falling into partiality, being experts in reasoning on the meaning of words" (MHK: 9.18). ${ }^{9}$ Thus, to recall Jonardon Ganeri's

\footnotetext{
${ }^{7}$ See: A. Laks, Histoire, Doxographie, Vérité, Études Sur Aristote, Théophraste Et La Philosophie Présocratique, Aristote, Traductions et Études, Louvain-la-Neuve 2007, p. 232.

${ }^{8}$ MHK, 9.19. Sampradāya-anupacchedād-āgamasya-āgamatvatạ̣ | sarvasya-āgamata-asiddheh kị̣ tattvam-iti dhāryatām $\|$.

${ }_{9} M H K$, 9.18. Tad-atra-api parīkșante yathā-bhūta-gaveșiṇạ̣ | pakșa-pāta-vișaṃ hitvā śabda-artha-nyāya-kovidāḥ \|.
} 
Concealed Art of the Soul, ${ }^{10}$ scriptures might serve as indicators pointing at the moon, but their understanding and communication depends upon reasoning. Yet hermeneutics is no absolute science, and anyone involved in its praxis knows that theories are only that, verbal proliferations (prapañca), some working tools at best, relative to a given context, or what the Buddha aptly called a "raft." This last consideration did not escape the three doxographers, and certainly informed their attitudes towards views in general and scriptures in particular. In any case, this realisation in no way dismisses the hermeneutical enterprise. On the contrary, it stresses the need for a rigorous methodology, a process of investigation which can be demonstrated. This is what darśanas convey: a rigorous hermeneutic praxis to both capture and convey the original insight of a tradition. The systematic development of darśanas gave rise to Indian scholasticism.

\section{Hermeneutics and dialectic as scholastic praxis}

Regarding sources of knowledge (pramāna) agreed upon in the Indian philosophical landscape, it is well known that interpretation (anumāna), commonly translated as inference, comes immediately after direct perception (pratyakșa) in terms of validity ${ }^{11}$ In the fourth century CE, the Buddhist logician Vasubandhu explained that there can either be inference for others (parärthānumāna) or inference for one-self (svārthānumāna). Mastering the art of inference, the interpretation of signs, is vital for hermeneutic praxis and debate, two essential components of scholasticism. It appears that, while inference for others was the golden way to debate, opening the doors to political power and scholarly fame, the importance of which ${ }^{12}$ can hardly be overstated in Indian culture, inference for one-self directly informs selfstudies (svādhyāya) and contemplation (bhävana). For example, while refuting the Mīmāmsā position on inference, Bhāviveka stresses the importance of that source of knowledge in an argument of deep consequences: "Because, if there is no convention to begin with, no ascertainment can be harnessed. Since [the conventional] has no beginning, being like samsāra, [ascertainment] is produced out of repeatedly corroborating the conventional" (MHK: 9.49) ${ }^{13}$ First, following Nāgārjuna, Bhāviveka equates conventions with samsāra. Both are without beginning. Then he goes on to

${ }_{10}$ That Indian traditions use scriptures as fingers pointing at the moon, and not as the moon itself, has been observed by Jonardon Ganeri who, having analysed the discourse of the Upanișads, the Nikāya and the Mahābhärata, noted that they have at least one thing in common: "[N]one of these texts merely puts the truth 'on display'. Each one, in its way, insists that discovering the truth, and in so doing freeing oneself of the deep errors in one's thinking about the self, is something the reader must do for themselves." J. Ganeri, The Concealed Art of the Soul, Theories of Self and Practices of Truth in Indian Ethics and Epistemology, Oxford 2012, p. 93.

${ }^{11}$ As there is an exception to every rule, the Mīmāmsākas will argue that the Veda, its word (śabda), is the only authority in matters imperceptible (adrșta).

${ }_{12}$ Stressed by the likes of Bimal Krishna Matilal and Amartya Sen.

${ }_{13}$ MHK: 9.49. Saṃketa-asaṃbhavād-ādau pratipattir-na yujyate | Saṃsāravad-anāditvāt saṃketasya-anuvādatạ̣ $\|$. 
state that the very possibility of knowing arises out of conventions, in other words out of samsāra. For him, as we shall see, knowledge is the cure of samsāric diseases. And, it is obtained by "repeatedly corroborating the conventional" (samketasyaanuvädatah), an act reminiscent of the mythical churning of the ocean, which is the activity of inference (anumāna), the essence of hermeneutics, to which Bhāviveka, loyal to the Buddhist tradition, subordinates the authoritativeness (pramannatva) of scriptures (ägama). Again, inference is not only a means of debates, but also one of self-transformation, moving from textual hermeneutics to the fundamental interpretation of samsāra, conventional existence itself. It is therefore inappropriate to reduce the praxis of dialectic to a mere intellectual enterprise exercised on the side of the path to liberation. Rather, it is part and parcel of its soteriological methodology.

In his brilliant work on Tibetan monastic education, Georges B.J. Dreyfus noted that: "scholastic studies should be seen not as directly preparing scholars for personal practice but as helping them to construct a cultural universe in which practice makes sense and to develop confidence in the soteriological possibilities of such a universe."14 To paraphrase Dreyfus, scholasticism is a stepping stone into the practice of the path, the axis of praxis. Without it, one is bereft of the insights of tradition, unprepared to deal with the many obstacles on the path.

For the self-understanding of our three thinkers, however, their hermeneutical efforts seem to be more than a mere stepping stone. In their eyes, valid cognition confirming scriptures through adequate reasoning is the very medicine that any seeker of truth strives for. The opposite is also true. As Haribhadra explains in his Yoga-drștisamuccaya (YDS): "Fallacious argument produces in the mind sickness of intellect, destruction of equanimity, disturbance of faith and cultivation of pride. In many ways, it is the enemy of existence" (YDS: 87).${ }^{15}$ In this context, engaging with views, rooting out fallacious arguments, is the praxis of a doctor interested in curing the sickness of samsāra. In his $M H K$, Bhāviveka effectively claims that: "By training in the view of the void, afflicted dispositions are destroyed, along with wicked deeds, the bondage of which is the doorway to all miseries" (MHK: 1.18) ${ }^{16}$ In his Upadeśa-Sāhasrī (US), Śankara makes a similar claim concerning the view of the Self. He notes that: "The Sruti says that, regarding the self, one who is convinced in the view that 'one is the Supreme Brahman' is never born again. Just as no fruit grows where there is no seed, there is no birth where there is no delusion" (US: 10.10). ${ }^{17}$ For our three authors, false views are like viruses infecting the mind with endless diseases, binding one to the sick-bed of samsāra, while the cultivation of the right view is like a therapy.

${ }^{14}$ G.B. Dreyfus, The Sound of Two Hands Clapping, the Education of a Tibetan Buddhist Monk, Berkeley 2003, pp. 164-165.

${ }^{15} Y D S, 87$. bodharogaḥ śamāpayah śraddhābhango'bhimānakṛt | kutarkaś cetaso vyaktạ̣ bhāvaśatrur anekadhā \|. All translations of the Yoga-drsțti-samuccaya are taken from C.K. Chapple, Reconciling Yogas, Haribhadra's Collection of Views on Yoga, with a New Translation of Haribhadra's Yogadr̦țisamuccaya by Christopher Key Chappel and John Thomas Casey, Albany 2003.

${ }^{16} M H K, 1.18$. Dauḥsíilyā-kriyayā sarva-durgati-dvāra-bandhanāt | Śūnyatā-darśana-abhyāsāt kleśavṛtty-upaghātatạ $\|$.

${ }^{17}$ US, 10.10. aham paraṃ brahma viniścayātmadṛn na jāyate bhūya iti ṣruteravacah | na caiva bīje tvasati prajāyate phalạ̣ janmāsti tato hyamohatā $\|$. 
The three agree that grasping and delusions fuel each other in an endless conundrum called samsāra. In the $Y D S$, the recognition of this deluded grasping is captured by two metaphors which Haribhadra gives as the common insight of eight different yogas known to him: "Like clouds that come and go in the night, like the graspings of a small child, so indeed is the view of the stream [of worldly existence] to be understood. Otherwise one is dwelling in a mistaken view" (YDS: 14). ${ }^{18}$ According to Haribhadra, the yogin must recognise the evanescent and attractive nature of mundane views for what they are, child's play, else his view is mistaken and he is no yogin. Hence, the practice of dialectic not only neutralises the venom of foreign false views, as a kind of philosophical vaccine, but it simultaneously highlights the inaccuracies of the mundane worldview one might entertain for oneself. Eltschinger observed a similar therapeutic dimension in the doxographical work of Sanntarikșita: "As Kamalaśîla insists, the doctrines Śāntarikṣita is concerned to refute all involve 'mistaken views of the self' (vitathätmadrsțti). As such, the importance of critical reflection upon them lies precisely in the fact that they are not just others' views of themselves, but that potentially at least, they are views that any of us may harbour, whether explicitly or not, with respect to ourselves. Śantarakșita's critical journey through the byways of Indian philosophy is therefore no mere exercise in doxography; rather, it is a therapy whereby one must challenge one's own self-understanding so as to disclose and finally uproot the misunderstandings that are concealed therein." ${ }^{19}$ Hence, the scholastic praxis of hermeneutics and dialectics is conceived as a critical means of self-transformation.

Recent writings by Paul Fuller and Albert Charles Muller have underlined how, from a Buddhist perspective, the most problematic aspect of views is not primarily their verifiability, but the way they influence behaviours. Accordingly, Buddhists interested in following the Eightfold Path laid down by the Buddha, beginning with the "right view," are encouraged to learn to discern between right and wrong views according to their behavioural impact. Here again tradition establishes a clear link between the way one thinks and the way one acts. Just as language in the eyes of Roland Barthes, views are never innocent. They influence the realm of karma. And since karma is the engine of samsāra, the endless flow of karmic retribution, views must be examined and neutralised in order to be free from sampāric miseries. Muller suggests that: "The notion of views is treated with decidedly more importance in Buddhism than in other religious traditions. ${ }^{20}$ Here I unfortunately disagree with him. Research on the traditions of our three doxographers indicates that Jainism, with its notorious theory of anekāntavāda, and Advaita-Vedānta, with its teachings on adhyāropa and apavāda, were equally concerned with views. This seems to be not only a PanIndian concern but one shared by numerous Western classical philosophers as well,

${ }^{18} Y D S, 14$. Sameghāmegharātryādau sagrahādyarbhakrādivat | Oghadṛștị iha jñeyā mithyādṛștịtarāśrayā $\|$.

${ }_{19}$ V. Eltschinger, op. cit., p. 30.

20 A.C. Muller, An Inquiry into Views: Lessons from Buddhism, Behavioral Psychology, and Constructivist Epistemology [in:] 2010 Civilization and Peace Beyond National Boundaries: Building a World without Walls, Seoul 2011, p. 164. 
as highlighted for instance by Martha Nussbaum's The Therapy of Desire. Pacifying views could also be of concern to the Yoga Sütras, which aims at mastery over mental operations (vrtti), if $d r \underline{s t ̦ i}$ (view) and vrtti were correlated. But, practically speaking, how does hermeneutic praxis fit in the path to liberation?

\section{A framework for the interplay of hermeneutic praxis and soteriology}

If one is to consider the Buddhist precursors of Bhāviveka, a theoretical framework outlining the pivotal role of reasoning and hermeneutics in early Buddhist religious praxis was already enunciated in the well-known third-century Yogācārabhümi. Its discussion on the three modes of insight (prajña $\bar{a}$ ) shapes the very structure of the soteriological process promoted three centuries later by Bhāviveka. It is stated therein that wisdom is progressively gained from hearing (śruta-mayi-prajū $\bar{a})$, re-

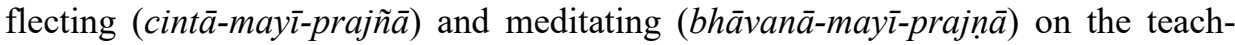
ings. Bhāviveka makes an explicit reference to this threefold scheme in his Karatalaratna: "In order to accumulate the eye medicine of unmistaken view of emptiness, one should rely on the wisdom obtained from hearing (śrutamay $\vec{l}$ ) which is able to remove the self-nature of all perceived objects." ${ }^{21}$ In Bhāviveka's program, the three modes of insights intend to highlight how one, desirous to progress from his conventional conceptual wisdom to the ultimate non-conceptual reality (paramārtha), first listens to the Buddha's teachings in order to obtain their profound meaning in terms of scriptures' semantics. One then applies reasoning unto such meaning to obtain knowledge both in terms of semantics and beyond it. Finally, meditation rests upon the knowledge gained beyond the language of scriptures altogether. This gradual threefold mode of insights into the nature of reality has also been asserted by other prominent Buddhist thinkers. Eltschinger has pointed out how Dignāga, Dharmakīrti and Kamalaśîla "consider the traditional sequence of insights as a self-sufficient means for securing enlightenment once the wrong notions spread and argued for by the outsiders have been discarded." 22 This suggests that although they did not attribute any soteriological value per se to the science of reasoning (hetuvidyā) alone, they saw it as a necessary step to refute possible wrong views one might entertain, before engaging in hermeneutic praxis proper, understood here as coinciding with hearing and reflecting upon the teachings of the Buddha.

Dreyfus noted that this model continues to inform the way in which Tibetans explain the soteriological value of their scholastic training. It represents a workable approach to contemplative practice, moving from grosser to ever subtler conceptual mental activities, acquiring certainty through logical analysis and inferential

${ }^{21}$ C.Y. Hsu, Bhāviveka's Jewel in the Hand Treatise: Elucidating a Path to Awakening Utilizing Formal Inference, Calgary 2013, p. 168. The KTR was translated into Chinese by Xuanzang around 647 or $649 \mathrm{CE}$, eighty years after Bhāviveka's death. This translation from Chinese was put together by Chien Y. Hsu, in her doctoral thesis.

${ }^{22}$ Ibidem, p. 172. 
reasoning, till concepts are completely transcended. Saussure's linguistic terminology could perhaps be applied to elucidate the different parts of the process. The acumen born of hearing engages with the "signifier." The acumen born out of thinking narrows on the "signified" and gives insight into the nature of the "linguistic sign" itself, while meditation is said to ultimately reveal the reality behind language altogether.

It is worth noticing that this threefold approach to the path is not limited to Buddhism, but similarly appears in the work of the two other doxographers. Haribhadra refers to an identical process when he claims that: "Through scriptures, inferences, and the essence of yoga practice, they succeed at the threefold wisdom and obtain the highest reality (tattva)" (YDS: 101). ${ }^{23}$ In his eyes, to hear the scriptures (agama), to reflect upon them through inferences (anumāna), and finally to engage in yogic contemplation (yoga-abhyassa) are the threefold components of the well-balanced therapy called yoga, what could be referred to as "yogic scholasticism." Similarly, Śankara, in a verse of deep Buddhist resonance, also stresses the significance of scriptural studies and reasoning in the soteriological process leading to self-discovery: "Thus, through reasoning and scriptures, like a lamp, the enlightened one, seeing [the Self] as homogeneous and hence as forever luminous, free from the duality that fancies existence and non-existence, is blown to complete extinction (nirvāna)" (US: 19.25). ${ }^{24}$ These brief examples, however short, suggest that our three authors envisioned their path as resting firmly upon hermeneutic praxis, making use of both scriptures and reasoning, in a model similarly developed within the Christian monastic culture of the High Middle Ages. ${ }^{25}$

The verse opening Bhāviveka's discussion on Mīmāṃsā, in the $M H K$, serves to illustrate how little sympathy the dialectician had for those who, unlike him, did not cultivate reasoned knowledge and meditation thereupon, but preferred to engage in ritualised activity: "Some, reviling the knowledge of and the meditation on the right path to emancipation, are the shameless to be discussed as [those] obtaining that [salvation] through ritual acts alone" (MHK: 9.1) ${ }^{26}$ The mere performance of acts (karman), be it Vedic sacrifice or anything else, for Bhāviveka as for our two other thinkers, cannot bring about the knowledge constitutive of enlightenment. Thus, to come back to our initial question, for them a genuine practitioner of yoga is intimately engaged in hermeneutic praxis, but not necessarily in the kinds of physical acts that came to be identified with Hatha-Yoga, nor even in the practices of Patañjali Yoga. As Halbfass underlined: "Śankkara's treatment of yoga practice is not so much an extension of his critique of Sāmkhya, but an expression and application of his general attitude toward 'works' (karman), and more specifically, of his rejection of the 'work orientation' of the Pūrva-mīmāṃsā. The 'mental acts' (mānasì kriyā) that

${ }^{23} Y D S, 101$. āgamenānumānena yogābhyāsarasena ca | tridhā prakalpyam prajñāṃ labhate tattvam uttamam $\|$.

${ }^{24} U S, 19.25$. samaṃ tu tasmāt-satatam vibhātavad-dvayād-vimuktaṃ sad-asad-vikalpitāt | nirīkṣya yuktyā śrutitas-tu buddhimān-aśeșa-nirvāṇam-upaiti dīpavat $\|$.

${ }_{25}$ The relation was made by G.B.J. Dreyfus, op. cit.

${ }^{26} M H K$, 9.1. eke'pavarga-sanmārga-dhyāna-jñāna-apavādinạ | kriyā-mātreṇa tat-prāptim pratipādya-anapatrapāḥ \|. 
constitute yogic meditation are not physical activities motivated by personal desires, and they are not rituals in a literal sense. They are nevertheless 'works', and oriented towards results. They are a part of that network of means and ends which keeps us in samsāara." ${ }^{27}$ Bhāviveka, rejecting any causal determinacy of nirvāna, though he surprisingly did not comment on any yoga darśana as such, took a relatively similar stance while discussing the Mīmāṃsā: "Because it is [mere] activity, like ploughing, one does not obtain liberation with a wishful [sacrificial] act. Either because it is expressly stated to be devoid of intelligence or because it is limited in time" (MHK: 9.22).$^{28}$ In brief, whatever is caused, by any act, is limited in time, hence not the kind of lasting liberation sought after, and mere activity alone does not cultivate one's knowledge, the essential ingredient of freedom. Henceforth, let it be clear, for Bhāviveka, as for Śañkara and Haribhadra, liberation comes from knowledge alone: "It should then be granted that, since it is the antidote to that [ignorance], liberation comes from knowledge; as one is freed from sickness out of medicine, because it is the antidote to illness" (MHK: 9.21). ${ }^{29}$ Notice here how Bhāviveka uses the simile of medicine to describe the effect of knowledge. The core problem being ignorance, its proper treatment is instrumented through knowledge and its means (pramāna). Hence, for our author, the cure for samsāra's illnesses is the therapy of hermeneutic praxis, the yoga of reason(ing).

But how useful, one may retort, can conceptual tools and views, signifying a nonconceptual reality, however well-reasoned, ever be regarding nirvāna? This apparent paradox suggests that while the study of views, by developing a palliative nonmundane view, is therapeutic, for it cleanses one from afflicted cognitive processes leading to grasping and so on, by introducing healthier patterns, this "palliative view" is not to be taken as health, or reality, itself. Just as Ganeri's remarks à propos the Upanișads, a given worldview (darśana) might be a finger pointing at the world, but it is never the world itself. In other words, the intellectual elaborations arrived at through reasoning, even though supported by scriptures, are no more than sand castles from the perspective of truth. The metaphor of the illusory palace to describe the liberating philosophical enterprise is indeed one cherished by Bhāviveka and captured beautifully, in its many shades, by Malcolm David Eckel: "Bhāvaviveka starts his analysis of reality with a reference to the steps of a palace. The steps that lead to the top of the palace represents stages in a process of reasoning that leads from the realm of ordinary thought to the realm of ultimate truth. The goal of the philosopher is to 'climb' to the top of the palace and see reality as it truly is. When the image of the palace next appears, it represents reality with ordinary values reversed: the structure that the philosopher once had to climb through a laborious process of conventional study becomes a palace seen in a dream. The physical act of climbing gives way to an instantaneous cognitive transformation. All a person has to do is wake up

27 W. Halbfass, Observations on Darśana, pp. 195-203.

${ }_{28}$ MHK, 9.22. Kriyātvān-na kriyā-abhīṣțā kṛ̣ivan-mukty-avāptaye | adhītve sati vācyatvān-mitakālatvato'pi vā $\|$.

${ }^{29} M H K$, 9.21. tatra tat-pratipakṣatvāj-jñānān-muktir-iti-iṣyatām | āmaya-pratipakṣatvād-auṣadhād vyādhi-muktivat $\|$. 
from the palace image as if waking from a dream. When the palace image appears for the last time, it represents conventional reality regained in the form of illusion." 30 Though ultimately illusory, the whole edifice of reason provides a ladder to reality. It is present before and after the path has been walked. Only one's perception of it changes. Once enlightened, the magical palace can now be summoned at will by the bodhisattva, for the benefits of all. His compassionate praxis will now consist in taking others up the stairways of the illusory palace, cutting through their delusions, one after the other: "He who completely cuts bondage with the sharp sword of wisdom is compassionate when he releases those who are not free" (MHK: 1.11) ${ }^{31}$ The sword of wisdom might be ultimately illusory, yet within the world of delusions it is sharp enough to strike a mortal blow.

\section{Conclusion}

In his book Absorption, one of the most insightful works on samādhi, Johannes Bronkhorst highlighted how the human faculty of speech is made possible by symbolic representation, a cognitive ability enabled by specific evolutionary features of the human brain. He elaborated on how these symbolic representations influence our cognition, leading us to experience the world in a dual manner: "A constructed world of symbolic representation is added onto a world of "raw" experience that underlies and accompanies it." ${ }^{32}$ The organising scheme of this world of symbolic representation, carrying emotional charges, could be called a view. These representations are collected in the mind like memory traces connected with bodily states. Unfortunately, they tend to create tensions in the human psyche. Bronkhorst elegantly developed a theory that endeavours to explain how absorption, as defined and cultivated in Buddhist practice, could ultimately pacify these tensions and produce a psychological state comparable to that of the Buddha.

While this approach is extremely useful, further research needs to be done not only on the therapeutic effects of absorption, when the symbolic mind is at rest, but on the therapeutic use of hermeneutics and dialectic in focusing and sharpening the mind through topical analysis, which might be called an intellectual form of meditative absorption. In other words, how could philosophical practice, through dialectic, hermeneutics and so on, contribute to the pacification of the mind of a subject engaged in the world of representations called samsāra? How could it contribute to, or cooperate with, various states of absorption? How could the practice of scholastic disciplines ensure psychological health, or how could a misguided practice lead to its ruin? In an age of extreme ideologies, where views too often carry a death sentence, the question is certainly not futile.

${ }^{30}$ D.M. Eckel, To See the Buddha, A Philosopher's Quest for the Meaning of Emptiness, Princeton 1992, p. 23.

${ }^{31} M H K$, 1.11. Prajñā-niśita-nistrimśa-cchinna-nihśeșa-bandhanaḥ| Mukto na mocayed-enān yadayaṃ karunātmakaḥ $\|$.

32 J. Bronkhorst, Absorption, Human Nature and Buddhist Liberation, Paris 2012, p. 21. 


\section{Bibliography}

Augustine T., Yoga Tantra: Theory and Praxis, in the Light of the Hevajra Tantra, a Metaphysical Perspective, Bibliotheca Indo-Buddhica Series, Delhi 2008.

Bronkhorst J., Absorption, Human Nature and Buddhist Liberation, Paris 2012.

Buescher J.B., Echoes from an Empty Sky. The Origins of the Buddhist Doctrine of the Two Truths, Ithaca 2005.

Chapple C.K., Reconciling Yogas, Haribhadra's Collection of Views on Yoga, with a New Translation of Haribhadra's Yogadrștisamuccaya by Christopher Key Chappel and John Thomas Casey, Albany 2003.

Dreyfus G.B.J., The Sound of Two Hands Clapping, the Education of a Tibetan Buddhist Monk, Berkeley 2003.

Eckel D.M., To See the Buddha. A Philosopher's Quest for the Meaning of Emptiness, Princeton 1992.

Eliade M., La Nostalgie Des Origines, Méthodologie Et Histoire Des Religions, Paris 1971.

Eltschinger V., Buddhist Epistemology as Apologetics, Studies on the History, Self-Understanding and Dogmatic Foundations of Late Indian Buddhist Philosophy, Beiträge Zur Kultur- Und Geistesgeschichte Asiens, vol. 81, Wien 2014.

Fuller P., The Notion of Ditthi in Theravāda Buddhism. The Point of View, Routledge Critical Studies in Buddhism, Oxon 2005.

Ganeri J., The Concealed Art of the Soul, Theories of Self and Practices of Truth in Indian Ethics and Epistemology, Oxford 2012.

Halbfass W., India and Europe: An Essay in Understanding, New York 1988.

Halbfass W., Observations on Darśana, "Wiener Zeitschrift für die Kunde Südasiens" 1979, vol. 23, pp. 195-203.

Halbfass W., Tradition and Reflection. Explorations in Indian Thought, Albany 1991.

Hsu C.Y., Bhāviveka's Jewel in the Hand Treatise: Elucidating a Path to Awakening Utilizing Formal Inference, Calgary 2013.

Laks A., Histoire, Doxographie, Vérité, Études Sur Aristote, Théophraste Et La Philosophie Présocratique, Aristote, Traductions Et Études, Louvain-la-Neuve 2007.

Muller A.C., An Inquiry into Views: Lessons from Buddhism, Behavioral Psychology, and Constructivist Epistemology [in:] 2010 Civilization and Peace Beyond National Boundaries: Building a World without Walls, Seoul 2011, pp. 159-193.

Nussbaum M.C., The Therapy of Desire, Theory and Practice in Hellenistic Ethics, Martin Classical Lectures, vol. 2, Princeton 1994. 